6. Gorynia, M. “Teoretyczne aspekty konkurencyjności.” Kompendium wiedzy o konkurencyjności, ed. M. Gorynia, E. Łaźniewska. Warszawa, Wydawnictwo Naukowe PWN, 2009.

7. Gorynia, M. "Konkurencyjność w ujęciu mikroekonomicznym.” Kompendium wiedzy o konkurencyjności, ed. M. Gorynia, E. Łaźniewska. Warszawa, Wydawnictwo Naukowe PWN, 2009.

8. Grzybowska, A. “Konkurencyjność przedsiębiorstw w obliczu procesów globalizacji.” „Ekonomia $i$ Prawo”, Tom XII, nr 3, 2013.

9. IMD, World Competitiveness Center, Defining International Competitiveness, Lausanne, 2019, www.imd.org/wcc/world-competitiveness-reflections/international-competitiveness/_Accessed 22.01.2020.

10. Jankowska, B., and M.Sulimowska-Formowicz. "Koncepcje konkurencji w ekonomii.” Kompendium wiedzy o konkurencyjności, ed. M. Gorynia, E. Łaźniewska. Warszawa,Wydawnictwo Naukowe PWN, 2009.

11. Jantoń-Drozdowska, E. “Globalizacja gospodarki i finansów.” Globalizacja. Wyzwania dla zarządzania i ekonomii, ed. E. Jantoń-Drozdowska. Poznań, Ars boni et aequi, 2008.

12. Jantoń-Drozdowska, E. Międzynarodowe stosunki gospodarcze. Poznań, Ars boni et aequi, 2009.

13. Jantoń-Drozdowska, E. "Międzynarodowa konkurencyjność gospodarki i regionu Unii Europejskiej." Determinanty konkurencyjności i ekspansji organizacji gospodarczych, ed. E. Jantoń-Drozdowska. Poznań, Wydawnictwo Naukowe UAM, 2019.

14. Jantoń-Drozdowska, E. "Makroekonomiczne uwarunkowania międzynarodowej konkurencyjności korporacji." Sotsial'no-kompetentne upravlinnya korporatsiyamy v umovakh povedinkovoyi ekonomiky. Luts’k, Skhidnoyevropeys’kyy Natsional’nyy Universyteet im. LesiUkrainki, 2020.

15. Jantoń-Drozdowska, E., and M. Majewska-Bator. "Kapitał intelektualny w gospodarce opartej na wiedzy.” Uniwersytet Szczeciński, „Zeszyty Naukowe”, no, 544, 2009.

16. Lubiński, M. Międzynarodowa konkurencyjność gospodarki. Pojęcie i sposoby mierzenia, Warszawa, IRiSS, 1995.

17. Nonaka, I., and H. Takeuchi. Kreowanie wiedzy w organizacjach. Warszawa, Poltext, 2000.

18. OECD Science, Technology and Industry Scoreboard 2009. OECD, doi.org/10.1787/sti_scoreboard2009-34-en Accessed 20.04.2019.

19. Penc, J. Zarzadzanie dla przyszłości. Kraków, Wydawnictwo Profesjonalnej Szkoły Biznesu, 1998.

20. Porter, M. The Competitive Advantage of Nations. New York, The Free Press, 1990.

21. Porter, M. Porter o konkurencji. Warszawa Polskie Wydawnictwo Ekonomiczne, 2001.

22. "Production and international trade in high-tech products, 2019." Eurostat, ec.europa/eurostat/statisticsexplained/index.php. Accessed 20.04.2019.

23. Sachwald, F. Competitiveness and Competition: which Theory of the Firm? w: European Integration and Competitiveness. Acquisitions and Alliances in Industry, ed. F. Sachwald, Edward Elgar. Aldershot,1994.

24. Stankiewicz, M.J. Konkurencyjność przedsiębiorstwa. Budowanie konkurencyjności przedsiębiorstwa w warunkach globalizacji. Toruń,Wydawnictwo TNOiK, “Dom Organizatora”, 2005.

25. The Knowledge-Based Economy, (2000), W: Science and Government Series, red. A. Kukliński, t. 5, Komitet Badań Naukowych, Warszawa.

26. World Investment Report 1999. New York, UNCTAD, 1999.

27. World Trade Organization. International Trade Statistics. New York, 2008, 2015.

УДК 339.7+330.322+323.21

doi: 10.15330/apred.2.16.17-28

\title{
МІЖНАРОДНІ ФІНАНСОВІ ІНВЕСТИЦІЇ ЯК ІНСТРУМЕНТ ПІДТРИМКИ РОЗВИТКУ ГРОМАДЯНСЬКОГО СУСПІЛЬСТВА
}

Івано-Франківський національний технічний університет нафти і газу, Міністерство освіти і науки України, кафедра менеджменту та адміністрування, вул. Карпатська, 15, м. Івано-Франківськ, 76019, Україна, 
тел.: 0342 72-58-75,

e-mail: reg@nung.edu.ua

Анотація. У статті досліджено особливості залучення міжнародних фінансових інвестицій в якості інструменту підтримки розвитку громадянського суспільства. В умовах обмеженого державного та регіонального фінансування зростає роль зовнішнього фінансування, джерелом якого виступає фінансовий ринок зарубіжних країн. Обгрунтовано актуальність залучення міжнародних фінансово-інвестиційних інструментів у розвиток громадянського суспільства та доцільність використання кращих практик ЄС щодо імплементації цінностей такого розвитку на основі Угоди про асоціацію з ЄС. Здійснено узагальнення передумов формування фінансово-інвестиційних інструментів. Визначено зміст фінансово-інвестиційних інструментів як джерела інвестиційної підтримки процесів розвитку та окреслено взаємозв'язок між фінансовим ринком та інвестиційним процесом як передумови формування міжнародних фінансово-інвестиційних інструментів підтримки розвитку громадянського суспільства. Виділено проектну діяльність як актуальну технологію інвестування в сучасних умовах, зокрема через фінансові інструменти Європейського Союзу (СС) та охарактеризовано основні етапи реалізації проектної ідеї, зокрема щодо розвитку громадянського суспільства. Узагальнено, що діяльність, пов'язана із залученням міжнародних фінансових інвестицій у підтримання прагнення громадян щодо спрямування власної ініціативи для реалізації цінностей, які притаманні громаді та відповідають громадянському суспільству, охоплює виявлення проблем, що перешкоджають цьому, аналіз наявних інвестиційних можливостей щодо вирішення цих проблем, виділення цільових груп, що зацікавленні у вирішенні проблеми, визначення видів діяльності, що дозволяють покращити ситуацію, підготовку відповідної проектної заявки щодо участі у відповідному міжнародному фінансовому інструменті, їі подання, а у випадку схвалення - реалізація усіх дій, передбачених у проекті та отримання задекларованих результатів та очікувань.

Ключові слова: міжнародні фінансові інвестиції, фінансовий ринок, розвиток громадянського суспільства, громада, проекти, фінансові інструменти

\title{
Polyanska A. S., Kochkodan V. B. INTERNATIONAL FINANCIAL INVESTMENTS AS CIVIL SOCIETY DEVELOPMENT SUPPORTING TOOL
}

\author{
Ivano-Frankivsk National Technical University of Oil \\ and Gas, \\ Ministry of Education and Science of Ukraine, \\ Management and Administration Department, \\ Karpatska str., 15, Ivano-Frankivsk, \\ 76019, Ukraine, \\ тел.: 0342 72-58-75, \\ e-mail: reg@nung.edu.ua
}

\begin{abstract}
The article examines the features of attracting international financial investment as civil society development supporting tool. In conditions of limited state and regional financing, the role of external financing is growing, the source of which is the financial market of foreign countries. The urgency of involving international financial and investment instruments in civil society development and the expediency of using EU best practices to implement the values of such development based on the Association Agreement with the EU are substantiated. The preconditions for the financial and investment instruments formation have been generalized. The content of financial and investment instruments as a source for development processes investment support is defined and the relationship between the financial market and the investment process as a prerequisite for the international financial and investment instruments formation of the civil society development support is outlined. The project activity is highlighted as a relevant investment technology in modern conditions, in particular through the financial instruments of the European Union (EU) and the main
\end{abstract}


stages of the project idea implementation are described with regard to the civil society development. In general, the activities related to the international financial investment attracting into supporting of the citizens' desire to direct their own initiative to implement the values inherent in the community and relevant to civil society, include identifying problems that prevent investment attraction, analysis of available investment opportunities to address these problems, selection of target groups interested in solving the problem, identification of activities to improve the situation, preparation of the relevant project application and its submission for participation in the relevant international financial instrument, and in case of approval - implementation of all actions envisaged in the project and obtaining declared results and expectations.

Key words: international financial investments, financial market, civil society development, community, projects, financial instruments

Вступ. Ситуація, у якій сьогодні опинився світ, характеризується складними наслідками, пов'язаними із економічною стагнацією, соціальними проблемами та усвідомленою необхідністю змінюватись. Україна та іiі громадяни все більше відчувають взаємозв'язок і взаємозалежність між подіями, які відбуваються у світі та їх наслідками і досвід протидії сучасній пандемії це засвідчив. Прагнення створити для усіх громадян рівні можливості для участі у прийнятті рішень щодо покращення економічної, соціальної, політичної, екологічної ситуації, а протягом останніх місяців боротьби з пандемією та іiі наслідками ставлять нові завдання перед світовою спільнотою, і Україна не повинна залишатись осторонь. Досягнути відчутних результатів можливо за рахунок імплементації вимог Угоди про асоціацію (УА), що дозволить гармонізувати умови життя громадян України відповідно до кращих практик EC.

3 огляду на це, міжнародна інвестиційна діяльність дозволяє об’єднати зусилля $\mathrm{EC}$, вітчизняних органів місцевого самоврядування, неурядових організацій та громадян України, а також зарубіжних партнерів, які спрямовують свою діяльність на консультаційну підтримку, для створення передумов та здійснення конкретних кроків щодо стимулювання розвитку, зокрема громадянського суспільства відповідно до умов УА.

Вагомий внесок у дослідження проблем організації інвестиційної діяльності, функціонування фінансового ринку, використання інструментів залучення фінансових ресурсів суб'єктами національної економіки зробили як вітчизняні, так і зарубіжні вчені, такі як: Л. Абалкін, Ф. Візер, Б. Гнатківський, В. Г. Дем'янишин, Ю. Б. Доброскок, Я. Б. Дропа, А. Г. Загородній, С. В. Захарін, М. І. Крупка, В. Кушлін, В. М. Легка, Т. В. Майорова, О. С. Маслова, В. Паретто, О. М. Підхомний, Н. П. Поляк, Г. Попов, М. Ю. Порвін, Л. О. Примостка, В. Ю. Прокопенко, Б. І. Пшик, З. Романчук, Е. Сапаров, О. М. Сохацька, О. О. Тіщенко, Г. Фостер, В. М. Шелудько, Т. В. Шталь та ін.

Питання розвитку суспільних ініціатив та практики самоорганізації громадян України в контексті формування громадянського суспільства розглядаються у працях [13-14], а також визначені Національною стратегією сприяння розвитку громадянського суспільства в Україні на 2016-2020 роки [15] та підтримуються вітчизняними активістами та експертами у даній сфері [16].

Віддаючи належне науковим напрацюванням вітчизняних та зарубіжних учених у дослідженні розвитку та функціонування фінансового ринку, варто зауважити, що деякі питання не знайшли свого вирішення або залишаються дискусійними, а саме мають бути розроблені конкретні кроки щодо стимулювання розвитку громадянського суспільства в регіонах відповідно до умов Угоди про асоціацію із залученням дієвих міжнародних фінансово-інвестиційних інструментів.

Постановка завдання. Метою даної статті $\epsilon$ дослідження особливостей залучення міжнародних фінансових інвестицій в якості інструменту підтримки 
розвитку громадянського суспільства. Відповідно до мети сформовано такі завдання: обгрунтувати актуальність залучення міжнародних фінансово-інвестиційних інструментів у розвиток громадянського суспільства; визначати зміст фінансовоінвестиційних інструментів, як джерела інвестиційної підтримки процесів розвитку та окреслити взаємозв'язок між фінансовим ринком та інвестиційним процесом; виділити проектну діяльність як актуальну в сучасних умовах технологію інвестування, зокрема через фінансові інструменти Свропейського Союзу (ЄС); охарактеризувати основні етапи реалізації фінансово-інвестиційних інструментів через проектну діяльність.

Результати. Важливим питанням на сьогодні $є$ створення передумов розвитку громадянського суспільства через посилення консультаційно-моніторингової діяльності, яка дозволить створити платформу, через яку жителі громад матимуть можливість звертатись і висловлювати своє бачення розвитку громад, зможуть приймати участь у іiі розбудові та спрямовувати власну ініціативу для реалізації цінностей, які притаманні громаді та відповідають громадянському суспільству. Якраз покращення інституційних умов дозволить не тільки розвинути ці цінності, але і гармонізувати їх із цінностями європейської спільноти. Реалізація даного завдання вимагає дієвих міжнародних фінансово-інвестиційних інструментів, які реалізуються, зокрема через проектну діяльність.

Національна економіка зможе розвиватися у випадку ефективного перерозподілу фінансових ресурсів між іiі секторами, а це можливо за умови функціонування фінансового ринку, який за допомогою фінансово-інвестиційних інструментів забезпечуватиме даний перерозподіл.

Під фінансовим ринком розуміємо систему кругообігу та перерозподілу фінансових активів між постачальниками i споживачами капіталу за допомогою спеціалізованих посередників на основі попиту та пропозиції на капітал. Фінансові ринки виконують важливі функції в соціально-економічному розвитку громадянського суспільства. До основних із них можна віднести трансформацію вільних нагромаджених коштів у позиковий капітал; об'єднання, консолідацію дрібних, розрізнених грошових заощаджень; фінансування держави, населення та інших суб'єктів економіки [1, с. 244].

Фінансово-інвестиційний інструмент - це особливий продукт фінансового ринку, який має форму договору або угоди і використовується для залучення фінансових ресурсів однією стороною й отримання прибутків та/або економічної вигоди - іншою. У процесі реалізації фінансово-інвестиційні інструменти перетворюються для їхнього власника у фінансові активи, а для емітента - у зобов'язання. Виняток становлять інструменти залучення фінансових ресурсів держави (податки та збори), оскільки вони регламентуються законодавством i $\epsilon$ обов'язковими для виконання, тому їхній адміністратор (уряд) отримує доходи для формування бюджетних ресурсів, а платники - право на якісну медицину, освіту, оборону, забезпечення порядку тощо. За їх допомогою держава здійснює перерозподіл ВВП і створює умови для фінансового забезпечення діяльності бюджетних установ та регулювання національної економіки [2, c. 684].

В міжнародній практиці під терміном «фінансово-інвестиційні інструменти» розуміють засоби інвестування (вкладення), придбання та розподілу капіталу, здійснення платежу та отримання кредиту (тобто фінансові активи і зобов'язання). Власне зазначений підхід до визначення фінансово-інвестиційних інструментів найбільше відповідає меті і завданням даної статті.

До фінансово-інвестиційних інструментів належать також різні види ринкових продуктів, що мають природу фінансів та $\epsilon$ засобом перерозподілу коштів. Їх використання $\epsilon$ основою функціонування складників фінансового ринку, тому 
розрізняють інструменти фондового, грошового ринків та ринку капіталу. До традиційних фінансово-інвестиційних інструментів належать депозитні, кредитні, страхові договори, цінні папери та ін., а до похідних - ф'ючерси, опціони, свопи, угоди за форвардними ставками тощо. Вони з'явилися на початку 80 -х років XX ст. і набули значного поширення в усьому світі. Депозитні корпорації та небанківські фінансові установи використовують похідні фінансово-інвестиційні інструменти як для отримання прибутку на фінансових ринках, так і для управління ризиками, тобто для хеджування [3, с. 44].

Питання залучення іноземних інвестицій для економічного зростання країни $\epsilon$ надзвичайно важливим, дискусійним і багато в чому невирішеним для багатьох держав. Мотивація іноземних інвесторів може бути різною, а їх діяльність, спрямована на задоволення власних інтересів, які не завжди співпадають 3 інвестиційними пріоритетами країни-реципієнта інвестицій [4, с. 237].

Необхідність залучення іноземних інвестицій в економіку України продиктована наступними чинниками: обмеженістю внутрішніх інвестиційних ресурсів; низькою інвестиційною активністю вітчизняних інвесторів; необхідністю залучення разом 3 інвестиціями нової техніки та технології; бажанням створити конкурентоспроможну економіку, освоїти світові ринки та розширити свою присутність на вже зайнятих; потребами в модернізації соціальної структури суспільства, створенням нових робочих місць.

Водночас розвиток зарубіжної інвестиційної активності країн-донорів зумовлений низкою причин: надлишком капіталів у країні; потребою в нових ринках збуту; потребою в економії на масштабах виробництва і досягнення максимуму ефективності на кожній зі стадій виробничого процесу; формуванням певного рівня конкурентоспроможності економіки; спробами обійти тарифні та нетарифні бар'єри в торгівлі; жорстким конкурентним та податковим законодавством окремих країн (для прикладу, США, чи країн (С), високими екологічними стандартами, витратами на заробітну плату; пошуком вищих норм прибутків на капітал; політичними чи соціальними мотивами тощо [4, с. 238].

Кошти іноземних інвесторів в країнах 3 розвиненою економікою $є$ суттєвим джерелом фінансового забезпечення інвестиційного процесу. В той час як в 2015 році частка прямих іноземних інвестицій в загальній структурі капітальних інвестицій в Україні становила близько $30 \%$, за результатами 2019 року дана частка вже була рівною $14 \%$ [5, с. 6], що підтверджує проблемність залучення фінансових ресурсів 3-за кордону в національну економіку. Існує ряд чинників, які призводять до негативного інвестиційного клімату в державі: недосконала законодавча база; не сприяння податкової системи розвитку підприємництва; низький рівень захисту прав потенційних інвесторів; системність корумпованості в органах державної влади та лобіювання власних інтересів державними службовцями; неефективна фінансова політика України; відсутність ініціативи власників підприємств щодо інвестування конкурентоспроможних інноваційних проектів; низький рівень життя громадян та зниження їх купівельних можливостей внаслідок інфляційних процесів [6, с. 164].

Формування привабливого інвестиційного клімату в Україні повинно бути першочерговим завданням як для внутрішньої, так і для зовнішньої політики держави. Серед основних позитивних кроків у цьому напрямку можна виділити наступні моменти:

- на території України до іноземних інвесторів застосовується національний режим інвестиційної діяльності, тобто надано рівні умови діяльності з вітчизняними інвесторами, іноземні інвестиції в Україні не підлягають націоналізації;

- у випадку припинення інвестиційної діяльності іноземному інвестору 
гарантується повернення його інвестиції в натуральній формі або у валюті інвестування без сплати мита, а також доходів від інвестицій у грошовій або товарній формі;

- усунуто адміністративний бар'єр для входження іноземного капіталу в Україну щодо обов'язковості реєстрації іноземних інвестицій;

- у правовій сфері відбуваються певні зрушення, зокрема $з$ метою сприяння залученню й ефективному використанню вітчизняних та іноземних інвестицій функціонує Рада вітчизняних та іноземних інвесторів [7, с. 123].

Роль фінансового ринку в реалізації інвестиційного процесу полягає не лише в забезпеченні останнього необхідними фінансовими ресурсами. Важливу роль відіграють й інші фінансові послуги, котрі лише опосередковано впливають на фінансове забезпечення інвестиційного процесу. Згідно із Законом України «Про фінансові послуги та державне регулювання ринків фінансових послуг» найважливішими 3 них є: випуск платіжних документів, платіжних карток, дорожніх чеків та/або їх обслуговування, кліринг, інші форми забезпечення розрахунків; довірче управління фінансовими активами; діяльність з обміну валют; надання гарантій i поручительств; переказ коштів; послуги у сфері страхування та у системі накопичувального пенсійного забезпечення; професійна діяльність на ринку цінних паперів, що підлягає ліцензуванню; факторинг; адміністрування фінансових активів для придбання товарів у групах [8].

Сьогодні фінансовий ринок $є$ головним посередником у процесах руху фінансових ресурсів, який обслуговується значною кількістю фінансово-інвестиційних інструментів, що формалізують і пришвидшують обіг капіталу, тому за сферами фінансової системи їх можна поділити на інструменти сектору державних i муніципальних фінансів та фінансового ринку. До першої групи належать монетарні, бюджетні, податкові, державні й інструменти фінансового ринку. Друга група охоплює муніципальні запозичення (місцеві органи влади здійснюють запозичення під час реалізації великих інвестиційних проектів), гарантії позик для третіх осіб, податкові і бюджетні інструменти. Кредитні інструменти та цінні папери належать до третьої групи [11, с. 256].

Взаємозв'язок між фінансовим ринком та інвестиційним процесом відбувається через фінансово-кредитні важелі, а саме: процентні ставки та умови надання фінансових кредитів; процентні ставки та умови залучення депозитів; страхові тарифи, умови страхування, порядок визначення і виплати страхового відшкодування; умови емісії, обігу та погашення цінних паперів; вимоги до діяльності фінансово-кредитних установ; умови обігу, обміну та курс валюти; умови емісії, та порядок використання платіжних карток. Отже, фінансовий ринок та інвестиційний процес тісно пов'язані між собою. Без фінансового ринку, його учасників та фінансово-інвестиційних інструментів реалізація інвестиційного процесу неможлива [1, с. 246].

Разом 3 тим, окрім можливостей, фінансово-інвестиційна діяльність вимагає обгрунтування іiі доцільності. Не завжди фінансовий результат є визначальним, а пріоритетними можуть виділятись соціальний, екологічний поступ, а також розвиток громадянського суспільства. Зазначене передбачає об'єднання зусиль приватного сектору, представленого жителями громад, органів місцевої влади, об'єднаннями експертів у сфері підтримки i розвитку підприємництва, зовнішньоекономічної діяльності та волонтерів, які спрямовані на поширення інформованості щодо пріоритетів та перспектив розвитку громадянського суспільства, організацію та проведення консультацій щодо реалізації передумов розвитку громадянського суспільства та здійснення моніторингу за такою діяльністю.

Політична та економічна нестабільність в Україні створюють перешкоди для соціального поступу. Не знаходячи підтримки з боку органів державної влади у 
вирішенні питань, пов'язаних із покращенням життєвого рівня населення, створенням сприятливих умов для реалізації підприємницьких ініціатив на місцях, значна частка населення залишає країну та шукає кращого майбутнього за кордоном. Проте значна частина населення не полишає надії вплинути на процеси змін, які дозволять кожному громадянину України долучитись до формування громадянського суспільства, завданням якого $є$ створення публічного простору, засобів та центрів комунікації, організація громадського життя із залученням незалежних від держави інституцій, діяльність яких зорієнтована на задоволення громадських інтересів та має на меті розвиток кооперації та солідарності між людьми, спілкування на засадах взаємної довіри і співробітництва.

Значним поштовхом до реалізації умов становлення та розвитку громадянського суспільства $\epsilon$ досвід європейських країн, юридичним підгрунтям до імплементації цінностей якого $є$ УА, а також ініціатива $\mathrm{CC}$ підтримати демократичний поступ, що реалізується у пропозиціях фінансових інструментів ЄС щодо участі у проектній діяльності. Тому на сьогодні важливо створити, а у випадках, коли така діяльність вже здійснюється, посилити підтримку ініціатив щодо розвитку громадянського суспільства на основі імплементації розвитку проектної діяльності. При цьому, визначальним та впливовим суб'єктом розбудови громадянського суспільства є організаційна підтримка такої діяльності, яка представлена неурядовими структурами чи соціальною мережею, що має на меті ініціювати та всебічно підтримувати громадян у їх прагненні долучитись до формування такого суспільства, яке у повній мірі зможе задовольнити їх вимоги щодо свободи та дієздатності приймати рішення, які стосуються розвитку громадянського суспільства.

Результати загальнонаціонального опитування населення України, проведеного 3 19 по 25 травня Фондом «Демократичні ініціативи» імені Ілька Кучеріва спільно 3 соціологічною службою Центру Разумкова, показали, що серед організацій громадянського суспільства найбільш впливовими і такими, що підтримуються громадянами України є громадські організації, волонтери та індивідуальні активісти. Проте найбільша довіра $\epsilon$ до волонтерів, які долучаються до процесів змін. За результатами проведеного опитування можемо зробити підсумок, що важливою умовою розвитку громадянського суспільства $\epsilon$ формування надійного і активного інституційного середовища, сформованого на базі діючих організацій громадянського суспільства та організація їх роботи на основі поширення відомостей та створення умов для імплементації УА [9].

Одним із завдань діяльності таких організацій є інформування про можливості розвитку громадянського суспільства, проведення консультацій щодо можливої участі у зазначених процесах та моніторинг досягнутих результатів.

Зазначимо, що напрями вирішення даних проблем передбачено у Програмі розвитку Івано-Франківської громади, зокрема на вирішення таких ключових проблем:

- брак досвіду роботи щодо стимулювання розвитку громадянського суспільства на основі УА;

- недостатнє інформування щодо імплементації УА з боку органів влади та неурядових організацій;

- недостатня аналітично-консультаційна підтримка стимулювання малого та середнього бізнесу на основі зарубіжного досвіду, технічна експертиза продукції, яка експортується, що гальмує успішну імплементацію УА;

- недостатнє залучення експертів та фахівців у створення умов для розвитку громадянського суспільства на основі реалізації заходів щодо імплементації УА.

Слід відмітити, що окрім зазначеного джерела фінансування, питання розвитку громадянського суспільства можливо вирішити шляхом залучення міжнародних 
фінансово-інвестиційних інструментів, що визначено у меті i завданнях окремо пропонованої проектної заявки. Наявність фінансово-інвестиційних інструментів, що відповідають потребам вітчизняних цільових груп, є важливим чинником зростання та підтримання ініціатив, зокрема щодо розвитку громадянського суспільства.

3 метою узагальнення викладеного вище та вироблення практичних рекомендацій щодо залучення фінансово-інвестиційного інструменту у розвиток громадянського суспільства, зокрема через проєктну діяльність, нижче виділено етапи та конкретні дії такої діяльності.

1. Реалізація міжнародних фінансово-інвестиційних інструментів вимагає визначення потреби щодо залучення інвестицій. Вирішення даного завдання відбувається на основі всебічного аналізу стану і тенденції інвестиційного процесу в громаді в контексті загального розвитку регіону, країни, міжнародної практики. Зазвичай фахівці використовують для цього стандартні методи статистичного та порівняльного аналізу, хоча доцільно також застосовувати сучасні економікоматематичні методи аналізу інформації.

2. На наступному етапі доцільно провести аналіз наявних міжнародних фінансових інструментів через аналіз проектних пропозицій $\mathrm{CC}$, а також вітчизняних інструментів реалізації інвестиційної політики. На сьогодні основними вітчизняними фінансовими інструментами інвестиційного розвитку регіону $\epsilon$ обласні цільові програми та обласний бюджет. При створенні обласної цільової програми інвестиційного розвитку регіону необхідно керуватися такими принципами:

- принцип взаємозв'язку та наступності програм (програми й проекти на кожному етапі реалізації повинні бути взаємозалежні за завданнями);

- принцип нарощування зусиль (необхідно забезпечити відтворення ресурсів у процесі реалізації стратегії, тобто можливість використати на наступних етапах ресурси, що були створені на попередніх етапах);

- принцип економії ресурсів (при розробці програми важливо, щоб ефект від іiї реалізації був ширший, ніж безпосереднє вирішення програмних завдань. Мова йде про створення загальних сприятливих соціальних, технологічних, інституціональних та організаційних умов, які підвищують загальну ефективність економіки, соціальної сфери);

- принцип «середовищного впливу» (програми повинні бути спрямовані на формування умов для вирішення певних проблем, наприклад, питання взаємодії влади і 3 організаціями громадянського суспільства за рахунок створення найбільш сприятливих умов для обміну думками, поглядами та шляхами вирішення проблем громадян);

- принцип інституціонального розвитку (ефективність програм визначається змінами в організаційній та інституціональній сферах) [12, с. 458-459].

3. Визначення цільових груп та бенефіціарів реалізації проектної ідеї за рахунок, зокрема міжнародних фінансових інвестицій. Цільовими групами можуть виступати суб'єкти приватного сектору, яка функціонує паралельно з державою та бізнесом та представлена організаціями громадянського суспільства, зокрема громадськими організаціями, професійними об'єднаннями, волонтерами, які приймають участь у суспільному житті громади. Нижче подано учасників потенційної цільової групи та основних бенефіціарів проекту щодо розвитку громадянського суспільства, що потребують залучення до проєкту та опис потреб, які будуть задоволені у його результаті, зокрема:

- суб'єкти підприємницької діяльності регіону (в основному суб'єкти малого і середнього підприємництва), які постраждали від пандемії та зменшили чи припинили свою ділову активність і для яких участь у проєкті дозволить удосконалити знання та 
навики з імплементації Угоди з СС на основі постійної інформаційно-консультативної підтримки. Згідно із результатами опитування суб'єктів підприємницької діяльності про наслідки пандемії на діяльність бізнесу, яке проведено у травні - червні 2020 року iз 40 респондентів різних видів діяльності, бізнес яких зареєстрований на території Івано-Франківської міської ОТГ, 12,5 \% припинили свою діяльність повністю, 35 \% тимчасово припинили свою діяльність, 37,5 \% - працювали не в повному обсязі, у 52,5 \% респондентів доходи скоротились більше ніж на 75 \%. Промисловість, роздрібна торгівля непродовольчими товарами, готельно-ресторанний бізнес, сфера обслуговування та розваг - галузі, які найбільше страждають від обмежень, введених у відповідь на поширення вірусу. Попри те, що частка готельно-ресторанного бізнесу в економіці є відносно незначною, в цьому секторі сконцентрована велика частка малих підприємств, які потребують підтримки. Оскільки 96,6\% від загальної кількості зареєстрованих підприємств становлять малі підприємства, то відповідно і фінансових ресурсів для діяльності в умовах безстрокового карантину у них надовго не вистачає. Як показало опитування, у 47,5 \% респондентів - фінансових ресурсів достатньо на менш, ніж на місяць, і у такої ж кількості респондентів - на період від 1 до 3 місяців. Найбільшої підтримки бізнес потребує в питанні зниження податкового навантаження (7 \%), фінансово-кредитної підтримки (47,5%), інфраструктурної підтримки $(20$ \%) [10];

- органи державної влади, органи місцевого самоврядування, які в результаті зниження довіри громади до політичних змін та в умовах пасивної інформаційної підтримки імплементації УА, отримають змогу розширити знання та навики фахівців, які взаємодіють з громадами в розрізі створення збалансованого партнерства між органами виконавчої влади, місцевою владою, бізнесом, громадою в питаннях імплементації Угоди з СС;

- мешканці, представники громад (ОТГ) - удосконалення знань та навиків про Угоду з СС завдяки постійній інформаційно-консультативній підтримці;

- інститути громадянського суспільства, які, зокрема, представлені організаціями, що підтримують та своєю діяльністю сприяють розвитку громадянського суспільства, в умовах зменшення довіри населення до урядових установ, політичних партій, індивідуальних активностей отримують платформу для спілкування 3 громадою та налагодження постійного діалогу та зворотного зв'язку між органами державної влади, галузевими об'єднаннями на населенням щодо імплементації Угоди з ЄС на основі постійної інформаційно-консультативної підтримки.

Окрім того, зазначимо, що залучення та реалізація сучасних фінансовоінвестиційних інструментів дозволить активізувати діяльність залучених до проекту волонтерів з боку ініціативної молоді, студентів, громадських активістів, експертів в питаннях місцевого розвитку та адміністративних реформ. Проектом передбачено залучення до співпраці підприємців, які припинили свою діяльність внаслідок пандемії, спричиненою вірусом COVID-19.

4. Виділення та обгрунтування основних напрямів та видів робіт із очікуваними результатами у межах реалізації визначеного фінансового інструменту. Вагоме значення для ефективної реалізації міжнародних інвестицій, зокрема щодо розвитку громадянського суспільства має досвід імплементації УА у країнах $€$, які його успішно реалізували та досягнули відчутних і видимих результатів. Відтак, поширення досвіду та кращих практик імплементації УА реалізується на основі залучення до співпраці іноземних представників аналітичних центрів та організацій громадянського суспільства. Для отримання результату від даної діяльності доцільною є організація візитів з обміну знаннями між громадянами $Є С$ та Україною, пов'язаними 3 виконанням УА, а також організацію зустрічей цільової групи на базі аналітичних 
центрів та у громадах із зарубіжними та вітчизняними експертами щодо підвищення обізнаності з діяльністю, спрямованою на сприяння співпраці між ЄС та Україною, з акцентом на економічну інтеграція та просування контактів між людьми. Враховуючи те, що представники цільової групи можуть мати труднощі із шляхами практичного застосування умов імплементації зарубіжного досвіду, необхідною є підтримка шляхом організації консультативного супроводу учасників цільової групи проекту щодо особистої участі у розвитку громадянського суспільства.

Створення умов для проведення моніторингу і навчання щодо імплементації заходів, пов'язаних із виконанням УА передбачає здійснення таких видів діяльності:

- проведення командою фахівців та запрошених експертів зустрічей із місцевими органами влади, бізнесом, громадою щодо інформування про умови та участь у створенні громадянського суспільства на основі УА;

- організування громадських зустрічей та експертних дискусій i діалогу між державними та місцевими органами влади, бізнесом та громадянським суспільством 3 питань, пов'язаних із виконанням Угоди про асоціацію;

- забезпечення виконання звітів моніторингу результатів участі у проєкті.

Здійснення такої діяльності вимагає проведення навчання для представників цільових груп. Таке навчання можливе за рахунок залучення фахівців у сфері міжнародної співпраці у питаннях імплементації УА, а також представників організацій громадянського суспільства, які мають досвід організації та проведення аналітичноконсультаційних та моніторингових заходів щодо імплементації УА. Формами навчання слугують тренінги, проведення консультацій, підтримання зворотного зв'язку та інформування про заходи щодо імплементації УА на основі створеної інформаційної платформи. Перелік заходів може бути розширено участю у спеціалізованих заходах, зокрема конференціях, форумах, практичних семінарах. Для забезпечення скоординованої та узгодженої роботи у вказаних напрямах передбачається розробка програмно-методичних матеріалів щодо проведення аналітично-консультаційної та моніторингової роботи у межах проєкту.

5. Важливим етапом є фахова підготовка проектної заявки щодо участі у відповідному міжнародному фінансовому інструменті, iї подання, а у випадку схвалення - реалізація усіх дій, передбачених у проекті та отримання задекларованих результатів та очікувань.

Висновки. Таким чином, дослідження особливостей залучення міжнародних фінансових інвестицій в якості інструменту підтримки розвитку громадянського суспільства дозволило сформувати нам такі висновки.

Сучасний ринок фінансових послуг створює широкі можливості для формування та реалізації фінансово-інвестиційних інструментів, спрямованих на процеси розвитку суспільства. Агрегування фінансово-інвестиційних ресурсів розвинутих країн, зокрема за рахунок коштів платників податків, а також використання фінансових ресурсів вітчизняних регіональних фондів розвитку акумулюють міжнародні та вітчизняні фінансово-інвестиційні інструменти, зокрема у розвиток громадянського суспільства.

Досягти підвищення ефективності фінансово-інвестиційної діяльності на рівні громад можливо через здійснення проєктної діяльності, на основі виконання основних вимог та етапів формування та реалізації проектної угоди. Саме за рахунок проектної діяльності для громад з'являються нові можливості реалізації цінностей громадянського суспільства за рахунок зазначених фінансових джерел. Враховуючи широкий перелік питань розвитку громадянського суспільства, зокрема консультаційно-моніторингової діяльності, та обмеженість фінансування за рахунок вітчизняних фондів, є необхідність у освоєнні міжнародних фінансово-інвестиційних інструментах. 
Сам зміст фінансово-інвестиційних інструментів, як джерела інвестиційної підтримки процесів розвитку дозволив окреслити взаємозв'язок між фінансовим ринком та інвестиційним процесом та виділити проектну діяльність як актуальну в сучасних умовах технологію інвестування, зокрема через фінансові інструменти Європейського Союзу (ЄС).

Характеристика основних етапів реалізації фінансово-інвестиційних інструментів через проектну діяльність дозволяє цільовим групам такого фінансування сформувати основний перелік робіт, які необхідно виділити, щоб реалізувати проекти у розвиток громадянського суспільства.

1. Майорова Т. В. Інвестиційний процес і фінансово-кредитні важелі його активізації в Україні: Монографія. К.: КНЕУ, 2013. 332 с.

2. Дропа Я.Б. Фінансові інструменти формування ресурсів у національній економіці в умовах глобалізації. Глобальні та національні проблеми економіки. 2017. № 16. С. 682-687.

3. Поляк Н. П. Кредитні інструменти розвитку реальної економіки в Україні: дис. ... канд. екон. наук: 08.00.08 / ДВНЗ «Університет банківської справи». Київ, 2016. 223 с.

4. Порвін М.Ю. Визначення шляхів вдосконалення державної інвестиційної політики в Україні. Наукові розвідки з державного та муніципального управління. 2013. № 1. С. 227-241.

5. Оцінка обсягів прямих іноземних інвестицій, в яких кінцевим контролюючим інвестором $\epsilon$ резидент (round tripping) за 2010p. - 2019p. Київ: Національний банк України, 2020. 14 с.

6. Гнатківський Б., Романчук 3. Проблеми залучення іноземних інвестицій в економіку України та шляхи їх вирішення. Вісник Львівського університету. Серія економічна. 2010. № 43. С. 162167.

7. Шталь Т. В., Доброскок Ю. Б., Тіщенко О. О., Сапаров Е. Аналіз інвестиційного клімату України та шляхи його вдосконалення. Бізнес Інформ. 2013. № 3. С. 122-125.

8. Про фінансові послуги та державне регулювання ринків фінансових послуг: Закон України від 12.07.2001 p. № 2664-III. Редакція від 04.10.2020. URL: https://zakon.rada.gov.ua/laws/show/266414\#Техt (дата звернення 10.10.2020).

9. «Громадянське суспільство в Україні: нові виклики, нові завдання». Результати опитувань. URL: https://www.ukrinform.ua/rubric-presshall/2508683-gromadanske-suspilstvo-v-ukraini-novivikliki-novi-zavdanna-rezultati-opituvan.html (дата звернення 10.10.2020).

10. Програма стимулювання економічного розвитку Івано-Франківської міської об’єднаної територіальної громади. URL: http://www.namvk.if.ua/ref_doc/77942 (дата звернення 10.10.2020).

11. Прокопенко В. Ю. Фінансово-кредитні інструменти на ринку нерухомості: дефініційні аспекти. Науковий вісник Львівського держсвного університету внутрішніх справ. Серія «Економічна». 2014. № 1. C. 247-259.

12. Захарін С. В. Теоретико-методологічні засади формування стратегічних орієнтирів інвестиційного розвитку регіонів. Наукові записки. Серія «Економіка». 2011. № 17. С. 454-460.

13. Розвиток громадянського суспільства в Україні: минуле, сучасність, перспективи: [колективна монографія / за заг. ред. О. М. Руденко, С. В. Штурхецького]. Острог: ІГСУ, Видавництво Національного університету «Острозька академія», 2014. 328 с.

14. Яблонський В. М., Вознюк П. Ф., Горєлов Д. М. [та ін.]. Розвиток громадянського суспільства в Україні: аналіт. доп за ред. О. А. Корнієвського, М. М. Розумного. К.: НІСД, 2015. 60 с.

15. Національна стратегія сприяння розвитку громадянського суспільства в Україні на 2016-2020 роки. URL: https://www.kmu.gov.ua/gromadskosti/gromadyanske-suspilstvo-i-vlada/spriyannyarozvitku-gromadyanskogo-suspilstva/nacionalna-strategiya-spriyannya-rozvitku-gromadyanskogosuspilstva-v-ukrayini-na-2016-2020-roki (дата звернення 15.10.2020).

16. Крупник A. Нова стратегія розвитку громадянського суспільства: як уникнути помилок. URL: https://www.pravda.com.ua/columns/2020/01/20/7237818/ (дата звернення 15.10.2020).

\section{References}

1. Maiorova, T.V. Investment process and financial and credit levers of its activation in Ukraine, KNEU, 2013.

2. Dropa, Ya.B. "Financial instruments of resource formation in the national economy in the context of globalization." Global and national economic problems, no. 16., 2017, pp. 682-687.

3. Polyak, N.P. Credit instruments for the development of the real economy in Ukraine. Diss. Kyiv, SHEI «University of Banking», 2016.. 
4. Porvin, M.Yu. "Identifying ways to improve public investment policy in Ukraine." Scientific exploration in state and municipal administration, no. 1, 2013, pp. 227-241.

5. Estimation of foreign direct investment volume with a resident as the final controlling investor (round tripping) during 2010 - 2019. Kyiv, National Bank of Ukraine, 2020.

6. Hnatkivskyi, B., and Z. Romanchuk. "Problems of attracting foreign investment into the economy of Ukraine and ways to solve them.” Bulletin of Lviv University. The economic series, no. 43, 2010, pp. 162-167.

7. Shtal, T.V., et al. “Analysis of the Ukraine's investment climate and ways to improve it.” Business Inform, no. 3, 2013, pp. 122-125.

8. On financial services and state regulation of financial services markets: Law of Ukraine. The Verkhovna Rada of Ukraine, zakon.rada.gov.ua/laws/show/2664-14\#Text. Acessed 10 Oct.2020.

9. «Civil society in Ukraine: new challenges, new tasks.» Survey results, www.ukrinform.ua/rubricpresshall/2508683-gromadanske-suspilstvo-v-ukraini-novi-vikliki-novi-zavdanna-rezultatiopituvan.html. Accessed 10 Oct. 2020.

10. "Program of economic development stimulation of Ivano-Frankivsk urban united territorial community.”Normatyvni akty Ivano-Frankivskoi miskoi rady, www.namvk.if.ua/ref_doc/77942. Accessed 10 Oct. 2020.

11. Prokopenko, V.Yu. "Financial and credit instruments in the real estate market: definition aspects." Scientific Bulletin of Lviv State University of Internal Affairs. «Economic» series, no. 1, 2014, pp. 247-259.

12. Zakharin, S.V. "Theoretical and methodological principles of strategic guidelines formation for investment development of regions.” Scientific notes. Economics series, no. 17, 2011, pp. 454-460.

13. Rudenko, O.M., Shturkhetskyi, S.V., eds. Development of civil society in Ukraine: past, present, prospects. Ostrog: IGSU, Ostroh Academy National University Publishing House, 2014.

14. Korniievskyi, O.A., Rozumnyi, M.M., eds. Development of civil society in Ukraine: analytic report. Kyiv,NISD, 2015.

15. "National strategy for promoting the development of civil society in Ukraine for 2016-2020.” Cabinet of Ministers of Ukraine, www.kmu.gov.ua/gromadskosti/gromadyanske-suspilstvo-ivlada/spriyannya-rozvitku-gromadyanskogo-suspilstva/nacionalna-strategiya-spriyannya-rozvitkugromadyanskogo-suspilstva-v-ukrayini-na- 2016-2020. Accessed 15 Oct. 2020.

16. Krupnyk, A. A. "New strategy for the development of civil society: how to avoid mistakes." Pravda, www.pravda.com.ua/columns/2020/01/20/7237818/. Accessed 15 Oct.2020.

УДК 331.55

doi: 10.15330/apred.2.16.28-36

\title{
СУТНІСТЬ МІЖНАРОДНОЇ МІГРАЦЇ̈ РОБОЧОЇ СИЛИ ТА ОЦНКА СУЧАСНОГО РІВНЯ ІНТЕГРАЦЇ̈ УКРАЇНИ В МІЖДЕРЖАВНИЙ РИНОК РОБОЧОЇ СИЛИ
}

\author{
Луцький національний технічний університет, \\ кафедра міжнародних економічних відносин, \\ вул. Ковалевська, 29, м. Луцьк, \\ 43000, Україна, \\ тел.: +380507578802, \\ e-mail: zelinska-olga@ukr.net
}

Анотація. Міграція робочої сили впливає на суспільне життя, і відіграє важливу роль у розвитку соціально-економічних відносин, що, у свою чергу, впливає і на політичний розвиток. Тому актуальність даної статті полягає в глобальності та швидкому зростанні внутрішньодержавних та міждержавних переїздів населення $\mathrm{i}$ трудових ресурсів у різноманітних формах, зумовлених, насамперед, нерівномірністю соціально-економічного розвитку країн.

Обсяги міжнародної міграції з кожним роком зростають. До неї залучається все більше 